\title{
Artistic depiction of mountain wave clouds: föhn clouds above Innsbruck
}

\section{Klaus-Peter Hoinka, ${ }^{1}$ Manuel de Castro ${ }^{2}$ and Reinhold Steinacker ${ }^{3}$}

${ }^{1}$ Institut für Physik der Atmosphare, DLR, Oberpfaffenhofen, Germany

2 Dpto. Ciencias Ambientales, ULCM, Toledo, Spain

${ }^{3}$ Institut für Meteorol ie und Geophysik, Universität Wien, Austria

The sixteenth century is notable for significant cartographical achievements such as the production of the first uniform atlases of the world; for example, the famous world map by Mercator in 1569. It also saw one of the first printed uniform collections of plans and cities of the world, the Civitates Orbis Terrarum by Georg Braun and Frans Hogenberg, which was published between 1572 and 1617. The Civitates Orbis Terrarum (henceforth COT), containing about 360 city maps mostly from Europe, forms a rich compendium of life in the sixteenth century (Skelton, 1965). It gives a visual printed record of the European Renaissance.

One of the COT copper engravings shows a city view of Innsbruck situated on the river Inn with its surrounding mountains. In contrast with the original copper engraving, which shows a weakly structured sky, a coloured version of this copper engraving contains a naturalistically painted sky including mountain-generated föhn clouds appearing above the Inn valley. These details were implemented to add aesthetic interest to the drawing of the city and to give a more vivid impression of the place and its environment, of course, but they also add typical local atmospheric features to the view of Innsbruck.

Clouds were part of the normal repertoire of Renaissance landscape painters and were used to strengthen aesthetically the dramatic context of the depicted situation. At that time the natural phenomena painted by artists, and recorded by chroniclers, were primarily very extraordinary events such as storms, lightning, floods and droughts. Less pronounced features received much such as a föhn, with its typical lee-wave clouds, is meteorologically significant but its visual attraction might not have appeared to an artist as dramatic as other atmospheric phenomena. This might be one reason why mountain-generated clouds received almost no attention from the Renaissance period until the end of the eighteenth century. The coloured city view of Innsbruck is one of the rare examples of mountain-wave clouds appearing in a Renaissance piece of art. This artistic depiction of föhn clouds, which shows mountain clouds clearly related to a specific orography, is probably one of the few representations of them in artworks until the eighteenth century and possibly the first appearance of northern Alpine mountain wave clouds.

\section{Mountain wave clouds in art}

A first example of mountain wave clouds appears in a small image, called Flight into Egypt, of a Gothic altarpiece The Adoration of the Magi by Gentile da Fabriano (c.1423) (Gedzelman, 2003). Contemporaneously mountain wave clouds appear in Masolino's Founding of Sta. Maria Maggiori (Figure 1) where several lines of lenticular clouds hover off the mountain range in the background. In spite of these impressive Gothic examples, clouds related to orography, such as lee-wave clouds, received almost no attention from Renaissance artists. One has to keep in mind, however, that it was no earlier than the Renaissance period when the painter's interest in natural phenomena began to emerge. The painters were dedicated primarily to following the ideal of aesthetic laws rather than natural laws. One must not forget that during this period the use of emblemata played an important role. Pictorial elements such as weather and clouds were employed to convey philosophical and political ideas through paintings and other pieces of art (Hoinka and Castro, 2003).

Gedzelman (1989) pointed out that 'Although clouds were depicted convincingly in the Renaissance period, the artists often showed apparent disregard for certain aspects of their form, particularly if seen through the parochial eye of a textbook meteorologist.' Pre-requisites for a naturalistic depiction

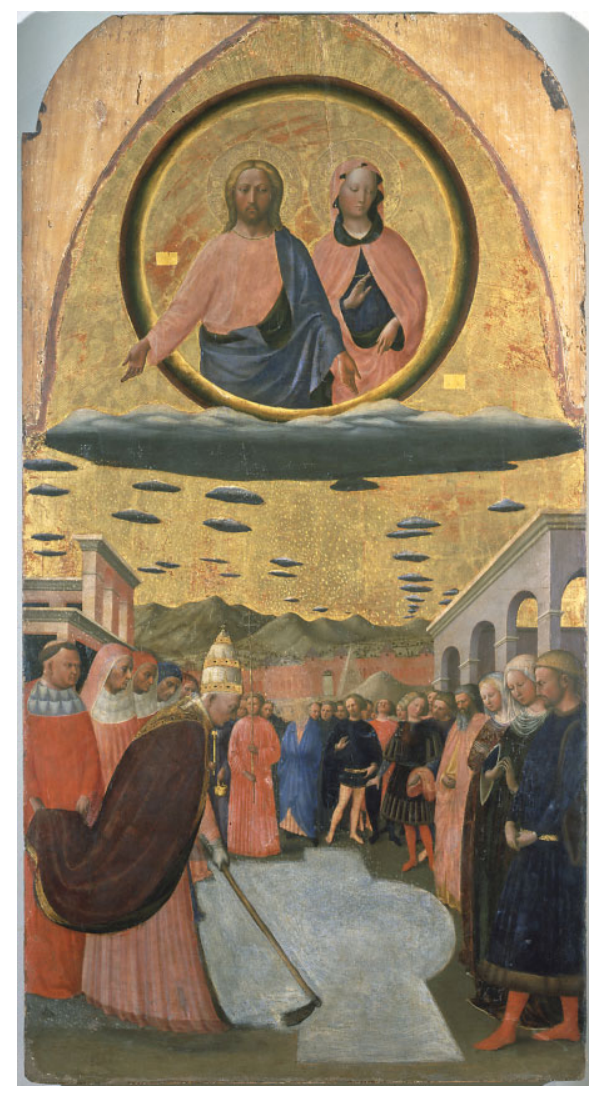

Figure 1. Mountain wave clouds in Masolino's Founding of Sta. Maria Maggiori (c. 1425). (৫) Museo di Capodimonte, Naples.)

of meteorological elements were the evolution and the establishment of meteorology as a science. In the Renaissance period, first attempts were undertaken to develop meteorology beyond the so-called astrometeorology ${ }^{1}$ towards science. First systematic meteorological observations were documented in Germany (1491); Austria (1500); Italy (1524); and Switzerland (1545) (Hellmann, 1901). However, the development of meteorology as an exact science was delayed until the seventeenth century, when the thermometer (1607) and the barometer (1643) were invented. Before this, interest in the weather expressed itself in

${ }^{1}$ A branch of Renaissance meteorology which dealt specifically with the forecasting of weather and other phenomena of nature based on astrology (Pogosyan, 1970). 
the form of individual weather notes and systematic weather journals, as well as in the first imperfect attempts to give some rules for predicting atmospheric phenomena. Kilian Leib, the Prior of the monastery at Rebdorf, near Eichstätt in Bavaria, produced some rules for predicting föhn in Bavaria. He took observations from day to day between 1513 and 1531. The monastery is located some $150 \mathrm{~km}$ north of the Alpine baseline. The Prior did not limit himself to the recording of facts, but even tried to verify the so-called peasant rules. One of these rules stated that rain was to be expected after a föhn accompanied by an exceptional view of the Alps from Eichstätt (Hellmann, 1915). This is a local weather rule which even today has not lost its usefulness. There is a strong link between the occurrence of föhn in Bavaria and the subsequent passage of a cold front (Egger and Hoinka, 1992).

In the seventeenth and eighteenth centuries, clouds received considerable attention in the Dutch landscape paintings. Although the great age of Dutch art offers prime examples of landscape paintings including clouds, examples of paintings showing orographic cloud formation are rare. Towards the end of this period, one outstanding example of mountain waves appears in the painting Ascent of a Montgolfier Balloon at Madrid (1784) by Antonio Carnicero (Gedzelman, 2003), showing cigar-shaped mountain wave clouds generated by the Sierra de Guadarrama to the north-west of Madrid. This is one of the few cases where mountain clouds appearing in a painting seem to be linked to a specific geographic location. In the eighteenth century, people began to travel far more widely. The Alps, which had earlier been considered only as a barrier, were beginning to be recognized for their beauty. Artists began representing these and other exotic places. Surely they saw clouds they never had seen before, but as long as they felt compelled to render clouds in conformity with current notions of the sublime, they performed poorly when it came to representing forms (Gedzelman, 1989).

It was not until the end of the eighteenth century that painters started to study the sky in a scientific manner and to recognize systematically and precisely the forms and formation of clouds in general and mountain-related clouds in particular. The aim was to understand nature as far as possible by use of artistic images. Advances in the scientific study of the atmosphere, led by the British naturalist Luke Howard (1772-1829), began to permeate artistic thinking in the early nineteenth century (Thornes, 1984). His Essays on the Modifications of Clouds dealt with a system of analysis for clouds, and suggested Latin nomenclature for types and subtypes. There is much historical evidence that the painter John Constable was informed of Howard's work. Bonacina (1937) pointed out that John Constable is acknowledged to be one of the earliest painters to observe the influence of topography on cloud forms in the early nineteenth century.

It was more than 300 years after the Renaissance that the meteorologist Julius Ferdinand von Hann gave the first physical explanation of the föhn (Hann, 1866). This thermodynamic theory includes obliquely the first explanations of clouds associated with föhn (Steinacker, 2006). At around the same time the depiction of föhn clouds became of strong interest for painters in the northern pre-Alpine foreland. North of Munich, in the Dachau area, several artists' clubs were established whose members painted views of the northern Alpine foreland and the mountain barrier from a distance (Reitmeier, 1989). Most of these paintings combine impressive landscape views with typical weather situations, such as föhn.

\section{Description of the Innsbruck view}

Figure 2 depicts the copper-engraved view towards Innsbruck seen from the west, sketched presumably by Joris Hoefnagel and engraved by Frans Hogenberg. This engraving is published as plate 42 in the second volume (1575) of the COT. From a bird's-eye view, the town of Innsbruck can be seen down-valley with the surrounding mountains on both sides of the Inn River. The perspective is modified by enlargment of the vertical axis so that one can see much detail in the town and at the same time appreciate the surrounding orography. The advantage of the bird's-eye view is that it shows features partly in elevation and partly in plan, a combination that makes them particularly attractive. The sky covers a big portion of the picture. The bridge crossing the Inn gave its name to Innsbruck because the old German word Bruck stands for Brücke (bridge). The Latin name is OENIPONS and it becomes 'Inßsprück' in sixteenth century script, as can be seen in the cartouche at the top, where the year 1575 is also written.

The Inn valley runs in a west-east direction with the river Inn flowing towards the image's background (Figure 2). For better geographical orientation Figure 3 shows the Alpine ridges and valleys as seen from a satellite on 2 February 2002. The white areas indicate snow-covered ridges and the dark areas are valleys. Northern Italy is covered by low-level clouds. The main ridges and valleys are roughly zonally oriented (Figure 3(a)). The Inn River valley runs (Figure 3(b)) towards the north-east leaving the Alps between Salzburg and Munich. Innsbruck is located in the Inn River valley at the junction with the Wipp valley (Sill River), which provides access to the Brenner Pass just $30 \mathrm{~km}$ to its south. In Figure 2 the Wipp valley enters from the right into the Inn valley but cannot be seen on the drawing.

In Figure 2, Hoefnagel increased the vertical scale by two in order to show Innsbruck more impressively by dramatizing the surrounding mountains. In Innsbruck, several church towers and houses can be

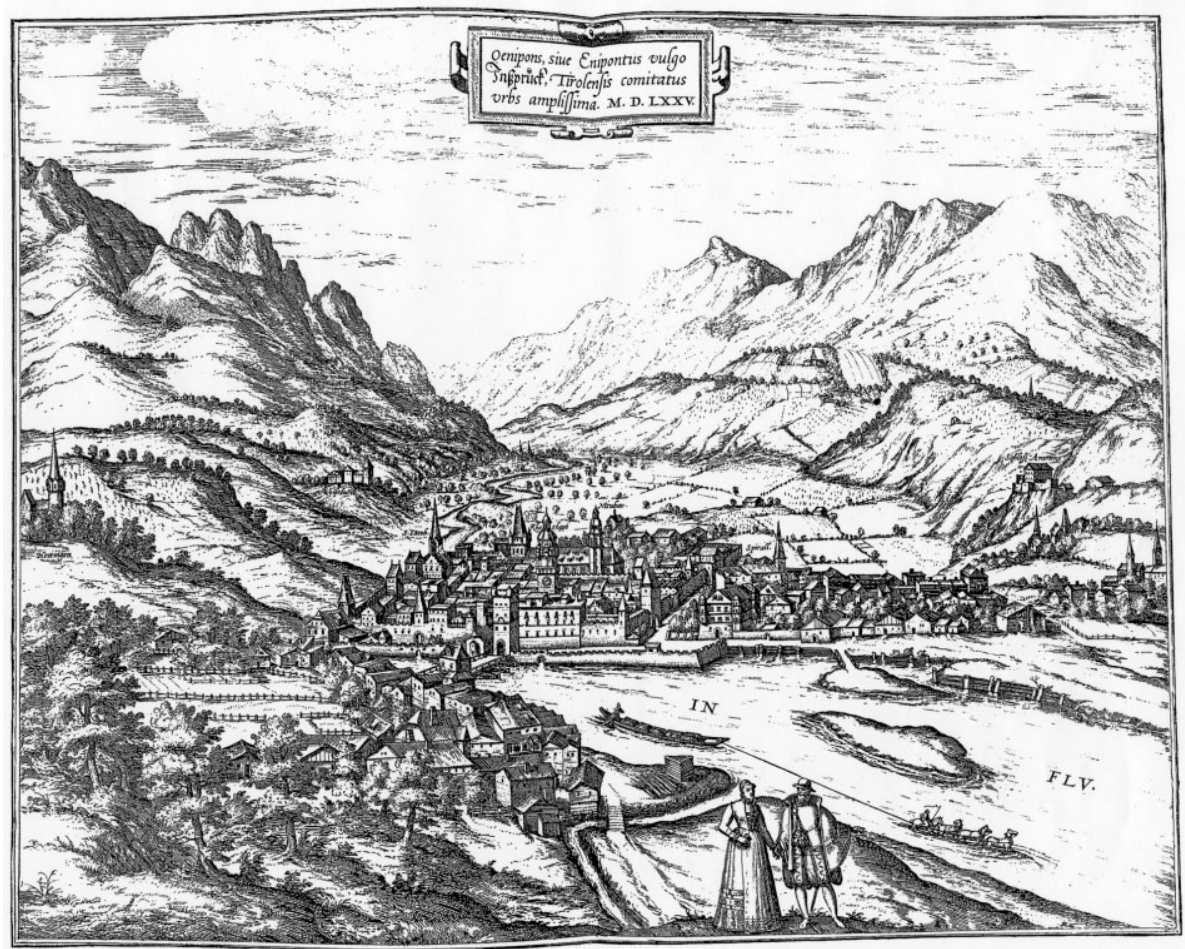

Figure 2. View toward Innsbruck from the west from Georg Braun and Frans Hogenberg's Civitates Orbis Terrarum (1575; Vol. II, Plate 42). Copper engraving of Frans Hogenberg. (@ Bayerische Staatsbibliothek, München.) 
recognized which are still existent today. The Habsburgian Castle Ambras can be seen on the descending mountains on the valley's right-hand side. The Karwendel Mountains to its left-hand side form a barrier to Bavaria. At the end of the nineteenth century the Inn was canalized. River traffic, particularly the salt trade, existed until the end of the eighteenth century downstream of Innsbruck. Tow-rope river traffic was further upstream, as can be seen in Figure 2 .

A distinctive feature of the COT plates is the insertion of a staffage ${ }^{2}$ of large figures in the foreground to illustrate local costume. These figures are out of proportion necessarily. Behind them Hoefnagel places the landscape in detail. His primary aim was not to produce well-balanced landscapes, but to give as much information as possible in a pleasant visual form, in reality a kind of guidebook, because he was mostly interested in educating the observer. This is also emphasized by Braun's explanations of the local staffage and the regional typical costumes in text added to each engraving. Small figures and groups of figures illustrate regional trades, handicrafts and agriculture. The staffage is used to enliven the landscape and the architectural composition. Keuning (1963) noted that Braun pointed out that the city views had been animated with human figures in order to prevent the Turks from being able to use the pictures in their wars of conquest, since their religion prohibits the portrayal of human beings.

\section{Depiction of föhn clouds}

A coloured version of the original copper engraving (Figure 2 ) is given in Figure 4. The colour was added to all printed engravings by hand until the mid-nineteenth century. The coloured issues were always based on the same black-and-white copper engraving but colours and styles differed according to the colourists' ability. Although a coloured model was generally followed, the application of the colours could vary considerably from one copy of a copper engraving to the next. The original engraving (Figure 2 ) shows a weakly structured sky without any distinctive cloud pattern; the coloured engravings differ strikingly. In most issues inspected by the authors in various libraries ${ }^{3}$ the sky is coloured without benefit of an organized cloud structure. There is one exception, which is given in Figure 4 and is reproduced in Iglesias (1998). This image shows the sky above the Inn valley with a clearly structured cloud pattern resembling to some extent the well-known föhn clouds.

${ }^{2}$ Staffage are ensembles of small figures and animals.

${ }^{3}$ For example, Bayerische Staatsbibliotkek München (Germany); Biblioteca Nacional Madrid (Spain); Biblioteca del Real Monasterio del Escorial, San Lorenzo de El Escorial (Spain); Stadtarchiv Innsbruck (Austria).
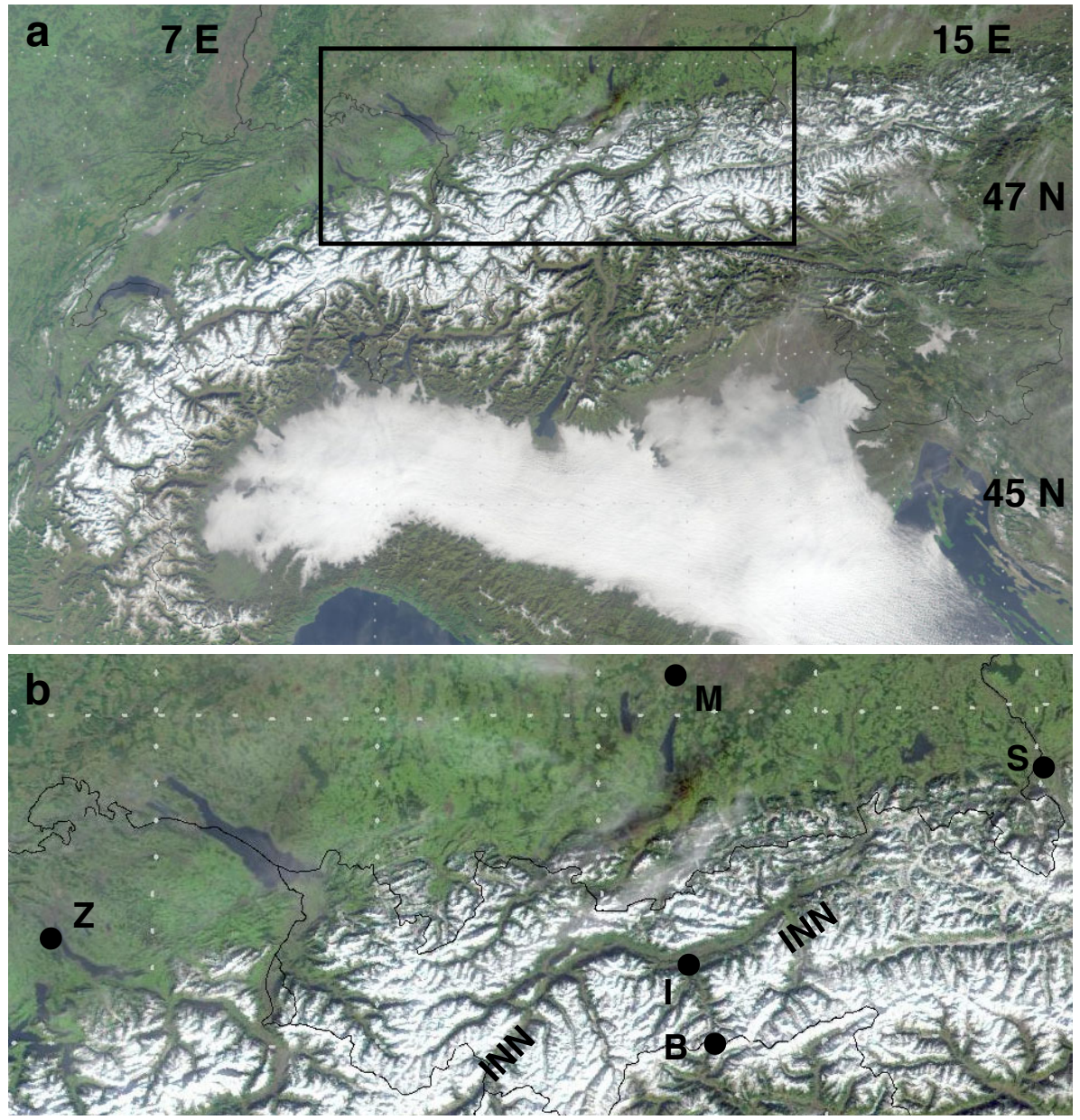

Figure 3. Satellite image of the Alps on 2 February 2002 of MODIS of NASA (a). The boxed area in (a) marks the enlarged part (b): Brenner Pass (B), Innsbruck (I), Munich (M), Salzburg (S) and Zürich (Z). (Courtesy of Thomas Gesell (DLR-DFD).)

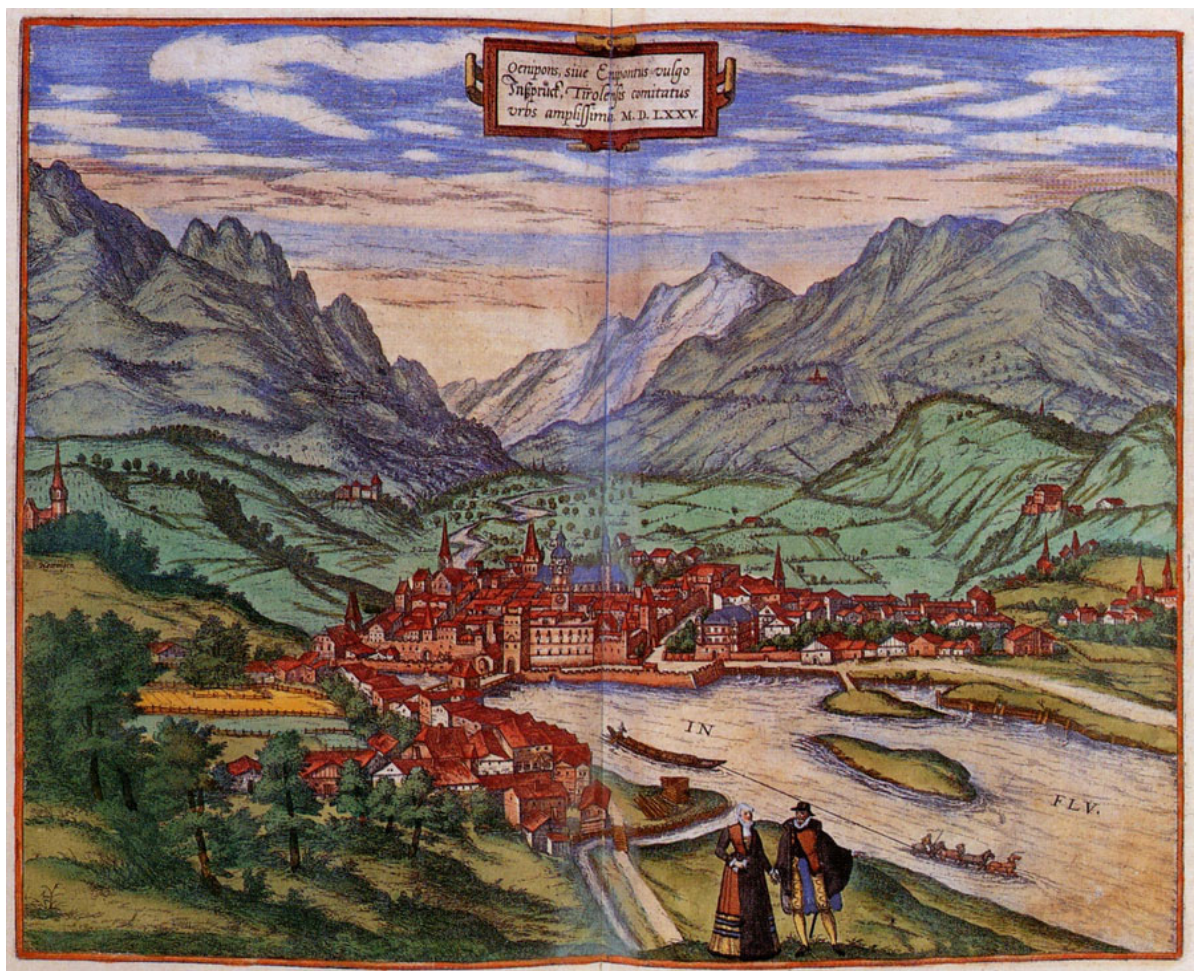

Figure 4. Same as Figure 2 but coloured, later than 1575. The picture is reproduced in Iglesias (1998; p. 86).

The colourful depiction of clouds (Figure 4) above Innsbruck was presumably added for decorative reasons because the coloured engraving gives a more vivid impression of Innsbruck and its environment than the original black-and-white (Figure 2). 
Besides the aesthetic element, the coloured engraving also exhibits a documental attitude by structuring the sky using a locally known meteorological feature. This attitude is merely recognizable here in the depiction of the naturalistic detail of the Alpine föhn clouds, but not in the presentation of a defined event with a specific date and time. Figure 4 shows white clouds hovering like fish over a sky which compares nicely to lenticular clouds. Behind them another elongated, more elevated cloud covers the sky, followed by a narrow cloud gap which is limited by overcast sky extending towards the valley's exit. The elongated clouds are oriented cross-valley.

Innsbruck is one of the places noted for frequent strong downslope windstorms such as föhn or chinook: other locations include Boulder (Colorado), Altdorf (Switzerland) and Calgary (Alberta). South-föhn (north-föhn) occurs as soon as there is a southerly (northerly) flow crossing the Alps. South-föhn occurs in Innsbruck for 50 days annually, usually in spring and autumn (Fliri, 1975). The basic synoptic structure during south-föhn is characterized by a trough located over the eastern Atlantic and a ridge of high pressure over eastern Europe (Drobinski et al., 2003). This results in a southwesterly flow across the Alps. Beneath this deep tropospheric cross-Alpine flow there is a near-surface shallow so-called gap-flow which flushes from the Brenner Pass down through the Wipp valley towards Innsbruck (Weissmann et al. 1999). The Alpine local peaks, ridges and valleys block and guide the flow and surface-bound southerlies occur in the Wipp valley, entering Innsbruck near the surface.

Within both flow layers, the tropospheric southwesterly flow and the southerly gap-flow, different clouds are generated. The gap-flow might force valley-parallel oriented mountain waves and clouds at crest height being to nearby local ridges south of Innsbruck. The southwesterly flow generates low-tropospheric lee-waves and clouds being oriented perpendicular to the main flow, which means that these lee-waves have a cross-valley orientation.

The artistic view given in Figure 4 depicts clouds associated with the low-tropospheric flow. The clouds, the elongated gap and the overcast areas are oriented from the north-west to the south-east, being in a perpendicular position to the valley. It was pointed out above that Hoefnagel put in small vignettes to illustrate local costumes and habits. The sky showing föhn clouds typical for the Innsbruck area adds a further local characteristic in the coloured version. This means that the author who coloured Hoefnagel's engraving presumably took into account Hoefnagel's intention and intensified the local character of the coloured engraving by adding a further local meteorological detail to the townscape of Innsbruck.

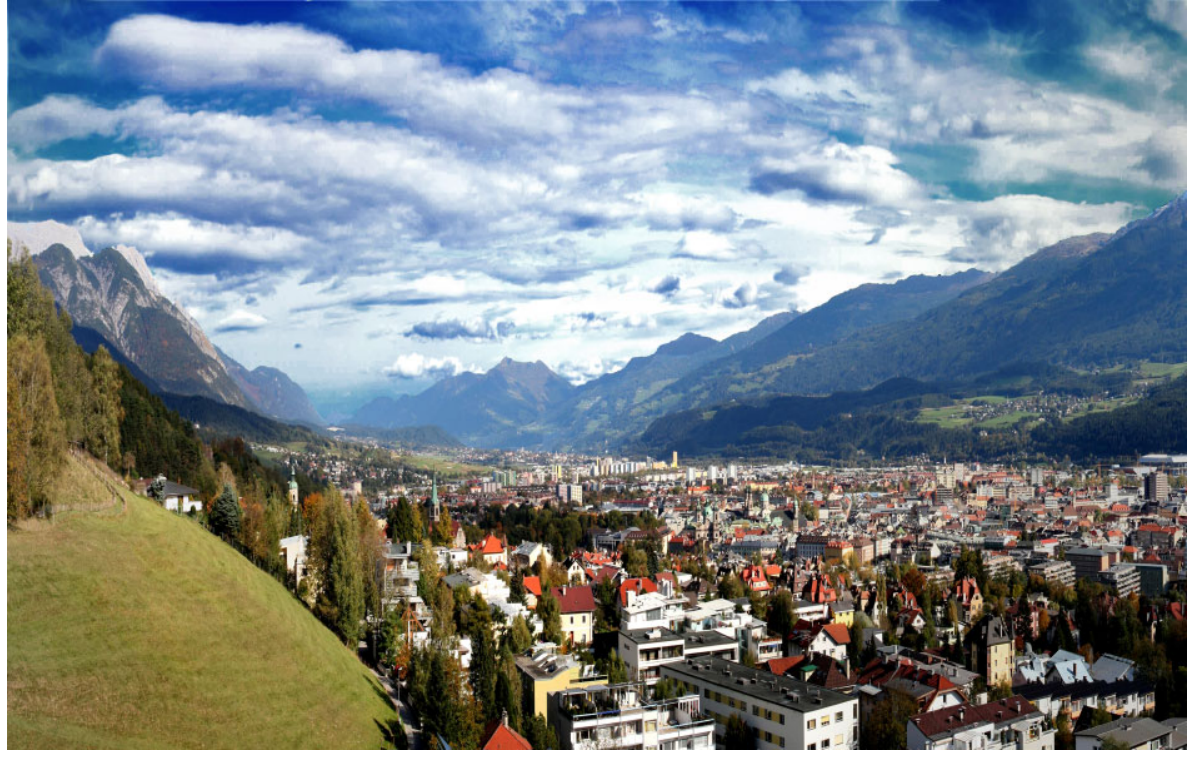

Figure 5. View towards Innsbruck from the west during the föhn of 20 October 2006 at 1300 UTC. The vertical scale is enlarged by two in order to better compare it with Figure 4. (๑ Reinhold Steinacker.)

To compare the painted structure given in Figure 4 with actual observations, Figure 5 depicts the cloud situation above the Inn valley during the south-föhn of 20 October 2006. The vertical scale is enlarged by two for a better comparison of the photo image with Hoefnagel's drawing. Additionally, the colours of the sky are slightly intensified to emphasize the cloud structure. We tried to take the photo from the approximate viewpoint of Hoefnagel's original engraving. This is not an easy task, because the bird'seye view is usually taken from a fictitious elevated position. One also has to keep in mind that the artistic realization is always an adaptation of the real view. In Figure 5, four to six lenticular clouds appear above the Inn valley at heights significantly greater than the surrounding mountains with crest heights of 1500-2000 m. These clouds are clearly related to the deep tropospheric flow and appear roughly in the same location as those in Figure 4.

The depiction of clouds suggests that the colourist must have experienced at least some south-föhn events in Innsbruck and was aware of this feature because he documents nicely the meteorological situation. One must even admit that he documents the situation astonishingly precisely considering the production period of the coloured engraving. Nevertheless, its artistic depiction cannot be assessed as perfect. The artistic quality of the coloured sky and clouds is not of a very high standard compared with cloud depictions by famous contemporary artists. One reason for this might be that at the end of the sixteenth century, city views were en vogue and much demanded by the public. These city views in the form of loose sheets (e.g. Figure 4) were produced in great numbers, a kind of 'mass production'. High-quality coloured engravings were sold for about double the price of black-and-white copper engravings. The growing public demand and the related mass production resulted in a lower price sometimes at the cost of artistic quality which varies from the sloppy to the superb, in terms of both execution and design, in the coloured versions.

Later on, loose black-and-white sheets were coloured in painting schools in order to train the painters' ability. Unfortunately, this allows one neither to name the author nor to denote the production year of the majority of the coloured engravings, such as the one given in Figure 4. It is later than 1575 but probably not later than the middle of the seventeenth century, when Hoefnagel's copper engraving was coloured. The original drawing of the Innsbruck view (Figure 2) is presumably by Hoefnagel although no mention is made on the picture. Another engraving is, however, signed by Hoefnagel ${ }^{4}$ (COT, Vol.V, plate 58), showing prominently the Habsburgian Palace of Ambras in a view looking from the east towards Innsbruck.

\section{The Civitates Orbis Terrarum}

For completeness a short discussion is given here on the production and importance of the COT. The editor Braun (1541-1622) and the engraver Hogenberg (1535-1590) started the publication of the first edition in August 1572 in Antwerp and Cologne simultaneously. ${ }^{5}$ Although COT is only the title of the first part, it is used for the entire six volumes.

COT was conceived and carried out under the general management of Braun, assisted by Cologne habitant Hogenberg, who

\section{${ }^{4} \mathrm{~A}$ list of all drawings originating from Hoefnagel} is given in Keuning (1963).

${ }^{5}$ The six volumes of the first edition were printed in Latin: I (1572); II (1575); III (1581); IV (1588); V (no later than 1598); and VI (1617) (Keuning 1963). 
engraved most of the views. Braun was principally responsible for the editorial work and had to find time in his busy life as priest, theologian and ecclesiestical administrator. The originals of city views and plans were taken by the editors from many sources. The printed maps relied mainly on existing maps, but also on maps made from drawings provided by Hoefnagel (1542-1600), who travelled in France and Spain, in the years 1561 to 1566, mostly in Andalusia, and then in England in 1568/1569 (Keuning, 1963). But in most cases the names of those who supplied the original pictures drawn on the spot remain unknown. Hoefnagel was the chief contributor as he provided the majority of the drawings. A detailed study on the production of the COT and on Hoefnagel's role is given by Popham (1936).

COT provides an uniquely comprehensive view of urban life at the turn of the sixteenth century. The copper-engraved city views, each accompanied by Braun's printed account of the town's history, situation and commerce, form an armchair traveller's compendium. The work was issued for sale to the public both in black-and-white and in colour. The views of the cities were sold separately, as well as collected into a volume, and loose sheets of the COT are in fact common (Skelton, 1965).

When the first atlas of Braun and Hogenberg's Civitates Orbis Terrarum was published, a new era of commercial cartography began and the popularity of maps increased. Moreover, increased travel stimulated the publication of books and prints on lands and cities near and far. In the preface to the second volume of COT, Braun stresses the benefits of foreign travel to learning, but also points out its danger and difficulties in the troubled times in which he lived. The possessor of the COT will be in the fortunate position of enjoying the benefits of travel without undergoing its discomfort and danger. This kind of comfortable travel was intended not only to give an artificial view of the local environment but to provide scientifically based information to educate the observer in local trades, handicrafts, and agriculture. The meteorological aspect, as exemplified by the coloured Innsbruck city view, was a further element of growing importance in the following decades. The coloured city view presented is of particular interest because it is probably one of the few depictions of mountain wave clouds associated with föhn related to a specific geographic location before the nineteenth century.

The number of educated men for whom any sort of foreign travel was possible must have been small in the sixteenth century. For the vast majority to be able to realize so clearly the physical character of great cities of the world, which they could never see, must have been an experience of which we can now hardly grasp the importance. The publication of the Civitates Orbis Terrarum with its wealth of accurately engraved views of places hitherto unknown, even in pictures, to so great a proportion of its possessors, must have been a sensational event (Popham, 1936). Finally, one should not forget that, although such literature was originally designated - like Baedeker - to be carried by travellers, it acquired an independent life of its own, as pointed out by Skelton (1965).

\section{Acknowledgements}

The authors wish to acknowledge technical support from Andreas Dörnbrack (DLR). Martin Commans of the Bookstore Hugendubel (Munich, Germany) is thanked for his help in searching literature.

\section{References}

Braun G, Hogenberg F. 1575. Civitates Orbis Terrarum, (6 parts in 2 Vol.), Colonia, Germany. (Faks. Edition, 1965: University Library of Amsterdam, 1618-1623.

Bärenreiter Verlag, Kassel, Germany).

Bonacina LCW. 1937. John Constable's Centenary: His position as a painter of weather. Q. J. R. Meteorol. Soc. 63, pp. 483-490.

Drobinski P, Haeberli C, Richard E, Lothon M, Dabas AM, Flamant PH, Furger M, Steinacker R. 2003. Scale interaction processes during the MAP IOP 12 south föhn event in the Rhine valley. Q. J. R. Meteorol. Soc. 129: 729-754.

Egger J, Hoinka KP. 1992. Fronts and orography. Meteorol. Atmos. Phys. 48: 3-36.

Fliri F. 1975. Das Klima der Alpen im Raum Tirol. Monographien zur Landeskunde Tirols I, Innsbruck.
Gedzelman SD. 1989. Cloud classification before Luke Howard. Bull. Amer. Meteorol. Soc. 70: 381-395.

Gedzelman SD. 2003. A history of the sky in art. Electronically available under: http://www.sci.ccny.cuny.edu/ stan/ skyart.html [accessed 11 December 2007].

Hann J. 1866. Zur Frage über den Ursprung des Föhn. Zeitschr. der österreichischen Gesellschaft für Meteorologie, 2: 257-263.

Hellmann G. 1901. Meteorologische Beobachtungen vom XIV. bis XVII. Jahrhundert. (Meteorological observations between the XIV and XVII century). Neudrucke von Schriften und Karten über Meteorologie und Erdmagnetismus (Ed. G. Hellmann), No.13. Verlag Asher, Berlin.

Hellmann G. 1915. Der Rebdorfer Prior Kilian Leib und sein Wettertagebuch von 1513 bis 1531. Meteorol. Z. 5: 236-238.

Hoinka KP, Castro M. 2005. A Renaissance depiction of a tornado. Bull. Amer. Meteor. Soc. 86: 543-552.

Iglesias MC. 1998. Felipe II, un monarca y su epoca. Catalogue of the Exhibition in the Real Monasterio de El Escorial, Spain. Keuning J. 1963. The civitates of Braun and Hogenberg. Imago Mundi, XVII, 41-44. Pogosyan Kh. 1959. Meteorology, A historical survey. Israel Program for Scientific Translations, Jerusalem, 1970.

Popham AE. 1936. Georg Hoefnagel and the Civitates Orbis Terrarum. Maso Finiguera, I, 183-201.

Reigmeier LJ. 1989. Dachau - der berühmte Malerort. Süddeutscher Verlag, München.

Skelton RAS. 1965. Braun and Hogenberg, Civitates Orbis Terrarum, the towns of the world. The World Publishing Company, Cleveland, USA

Steinacker R. 2006. Alpiner Föhn - eine neue Strophe zu einem alten Lied. Promet, 32: 3-10.

Thornes JE. 1984. Luke Howards's influence on art and literature in the early nineteenth century. Weather 39: 252-255.

Weissman MD, Mayr GJ, Banta, RM,

Gohm A. 1999. Observation of the temporal evolution and spatial structure of the gap flow October 1999. Mon. Wea. Rev. 132: 2684-2697.

Correspondence to: Klaus P. Hoinka, Institut für Physik der Atmosphäre, DLR, Postfach 1116, Oberpfaffenhofen, $D-82230$ Wessling, Germany.

Email:klaus.hoinka@dlr.de

(c) Royal Meteorological Society, 2008

DOI: 10.1002/wea.185 